\title{
Agricultural Research Policy in an Era of Privatization
}

Edited by D Byerlee. The World Bank, and R G Echeverria, Inter-American Development Bank, Washington DC, USA

ISBN

0851996000

June 2002

320 pages

Hardback

$£ 49.95$ (US\$75.00)

\section{Readership}

Agricultural economics, policy and development. Ag-bio industries including biotechnology.

\section{Description}

Recent decades have witnessed a dramatic shift from public to private sector agricultural research in many developed countries. Developments in plant breeding and biotechnology, for example, have created profitable opportunities for private investment. However, new issues, such as intellectual property rights, have arisen as a consequence. This book discusses these and related issues.

\section{To view full contents or to order online please visit wuw.cabi-publishing,org/bookshop}

Postage \& Packing: For pre-paid orders in the UK, please add $£ 2.75$ for the Ist book and 60p for each additional book ordered (up to max. of 10). For pre-paid orders elsewhere, please add $t 4.00$ for the Ist book and 61.00 for each additional book. For orders not pre-paid, postage and packing will be charged according to the weight of the book.
CABI Publishing, CAB International Wallingford,

Oxon OX10 8DE, UK Tel: $+44(0) 1491832111$

Fax: +44(0)1491 829292

Email: orders@cabi.org
CABI Publishing North America

44 Brattle Street, 4th Floor

Cambridge, MA 02138, USA

Tel: 0016173954056

Fax: 0016173546875

Email: cabi-nao@cabi.org 


\section{organic-research.com}

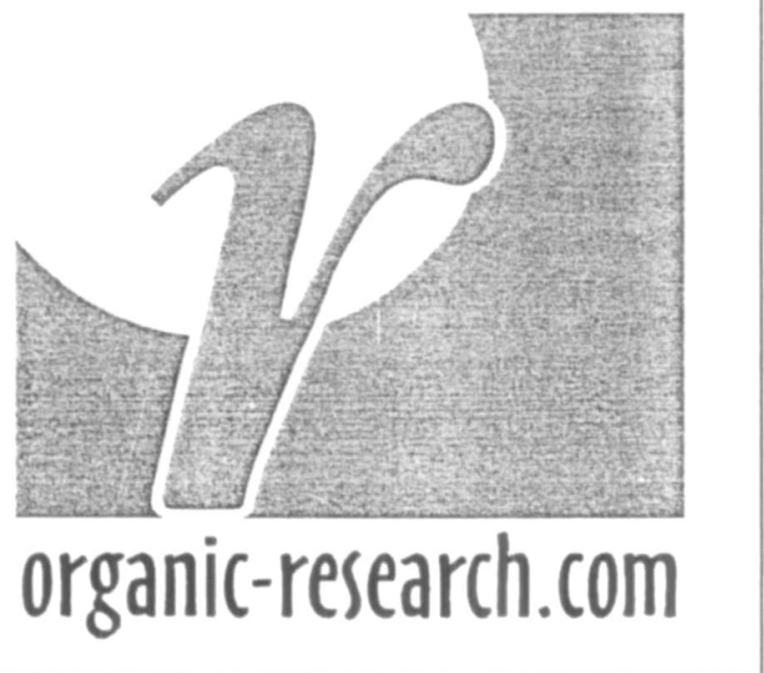

organic-research.com is an online resource for organic farming and food, developed by $C A B I$ Publishing.

The heart of organic-research.com is an abstract database which provides internet access to summaries of the world's published literature in organic farming. The database contains over 110,000 records, with hundreds of new records added every two weeks. organic-research.com also contains up-todate information on:

- Events

- Jobs

- Education

- Laws and Regulations

- Newsletter
- News

- Research

- Farms

- Books

- Links

organic-research.com will be of particular relevance to those actively involved in organic farming research development. But anyone interested in organic food and its production will find this site invaluable. CABI Publishing aims to provide impartial information of high quality, recognizing worldwide interest in organic farming and related sustainability.

\section{Visit www.organic-research.com today}




\section{Guide for Authors}

The American Journal of Alternative Agriculture publishes original research on biological, physical, or social science aspects of alternative and renewable agriculture and food systems. We particularly welcome multidisciplinary studies, but papers from a specific discipline also are invited. However, since AJAA readership is much broader than for a single-discipline journal, highly specialized terminology should be explained or avoided. The significance of a statement, or the reasoning behind a conclusion, may have to be spelled out more than in a more specialized journal. See http://www.cabi-publishing.org/journals/ajaa for an explanation of the various categories of articles.

Units. Research papers should use the International (SI, or metric) system throughout. Occasional use of common unit equivalents in parentheses is permitted.

Title Page. The title page should give the following information (all flush left): 1) title of the paper; 2) names of the authors; 3) affiliation and office address of authors, and 4) disclaimers, if any.

Abstract. The abstract should be 200 to 400 words, suitable for readers from a broad range of disciplines. It should avoid highly-specialized terminology that might be appropriate for a single-discipline journal. Take particular care that the significance of the work is made clear, even to readers from a different field.

Key Words. Provide subject matter key words suitable for use in scientific indexing.

Reference List. References should be listed in alphabetical order by author's name, and by year for a particular author (with letters after the year if needed). If a sole author is also the lead author of papers with multiple authors, use the following order: single author (by year); two authors (alphabetically by second author's name); three or more authors (by year). Repeat the author's name for each reference. Give the names of all authors in the reference, never use "et al."

Use full names of journals, institutions, conferences, etc. The reference list uses no quotation marks, italics, boldface or underlining. Only the names of books and periodicals are in initial capitals. Names of papers, book chapters, pamphlets, and bulletins are not capitalized.

Examples:

Arshad, M.A. and Coen, G.M., 1992. Characterization of soil quality: Physical and chemical criteria. American Journal of Alternative Agriculture 7:25-31.

Brink, R.H. Jr, Dubach, P., and Lynch, D.I., 1960. Measurement of carbohydrates in soil hydrolyzates with anthrone. Soil Science 89:157-166.

Coale, F.J. 1996. Descriptions of the soil test interpretive categories used by the University of Maryland Soil Testing Laboratory. SFM-3. University of Maryland, College Park.

Greenland, D.J., and Szabolcs, I., (eds). 1994. Soil Resilience and Sustainable Land Use. CAB International, Wallingford, UK.

Leopold, A. 1991. The farmer as a conservationist. In S. L. Flader and J. B. Callicott (eds). The River of the Mother of God and Other Essays by Aldo Leopold. University of Wisconsin Press, Madison, WI. p. 255-265.

Citing References. Cite references in the text by last name and year, with chapter or page numbers if the reference is a book or lengthy report. For two authors, give both names. Do not use "et al." unless there are three or more authors.
Footnotes. AJAA does not use bibliographic or substantive footnotes. All bibliographic references should be at the end of the text. Instead of substantive footnotes, include the material in the main text or consider eliminating it.

Manuscript Preparation. The entire manuscript, including abstract and references, should be typed on one side of standard-size paper, double spaced, with margins of at least one inch all around. Starting with the title page, label all pages in the upper right-hand corner with the lead author's last name and the page number. Do not use hyphens unless the hyphen is part of the word. Indicate on the title page who the corresponding author is, and supply a present postal address, fax number and email address. The email address is particularly important because page proofs will be sent electronically as a PDF file to the corresponding author for checking (see 'page proofs' section below for more detail). Tables should fit on one page, be numbered consecutively with Arabic numerals, and be on a separate sheet. Every figure and table should be mentioned at least once in the text. A detailed guide to formatting is available from the editorial office (address below)

Submission of manuscripts. Submit two high-quality copies (including any artwork), plus preferably a Microsoft Word disc version, to:

American Journal of Alternative Agriculture

clo Emma Durman

CABI Publishing

Nosworthy Way

Wallingford, Oxon OX10 8DE

UK

Email: ajaa@cabi.org

The cover letter should state that the manuscript is an original contribution that has not been published elsewhere in substantially the same form, that it is not currently under consideration elsewhere, and that permission has been obtained for any copyrighted material used.

Copyright. Papers are accepted on the understanding that the work has been submitted exclusively to the Journal. Authors will be supplied with a copyright form which must be completed and returned to the publisher. Papers will not be published until the signed copyright disclaimer has been received.

Page Proofs. Once typeset, the corresponding author will receive page proofs by email as a PDF file. You will be asked to print the PDF proof and mark any corrections to the printout before mailing back to $C A B I$ Publishing, or alternatively, detailing your corrections in an email to the Production Editor.

Offprints. Along with your PDF proof, you will also be emailed an offprint order form. If you wish to order offprints of your paper, complete this form using the price scale provided and return it with your corrected proof to $\mathrm{CABI}$ Publishing. However, if you do not wish to go to the expense of purchasing paper offprints, please be aware you will be provided with a final PDF file by email at no expense.

\section{A Final Note}

Articles will be considered for publication in the AJAA only when submitted formally, in their final form, and formatted to the style of the AJAA. 


\section{AMERICAW JOURHAL OF ALTERMTIUE AGRICULTURE}

\section{Editorial}

John W. Doran and Sarah Peck

173

Building diverse community networks for sustainable food systems: Guiding philosophies of the Pennsylvania Association for Sustainable Agriculture Laura M. Carnes and Heather D. Karsten

Gender issues in family poulty production systems in low-income food-deficit countries

E.F. Guèye

Economic viability of the traditional farming system in the Ghouta,

Oasis of Damascus, Syria

Sameer K. Alhamidi, Bengt Hảkansson and Mats Gustafsson

The farmer as conservationist

Catherine Badgley

Consumers' preferences for locally produced food: A study in southeast

Missouri

Cheryl Brown 